Purdue University

Purdue e-Pubs

Purdue CIBER Working Papers

Krannert Graduate School of Management

$1-1-2001$

\title{
The Value Relevance and Reliability of Brand Assets Recognized by UK Firms
}

Sanjay Kallapur

Purdue University

Sabrina Kwan

Hong Kong University of Science and Technology

Follow this and additional works at: http:// docs.lib.purdue.edu/ciberwp

Kallapur, Sanjay and Kwan, Sabrina, "The Value Relevance and Reliability of Brand Assets Recognized by UK Firms" (2001). Purdue CIBER Working Papers. Paper 18.

http://docs.lib.purdue.edu/ciberwp/18

This document has been made available through Purdue e-Pubs, a service of the Purdue University Libraries. Please contact epubs@purdue.edu for additional information. 


\title{
The Value Relevance and Reliability of Brand Assets Recognized by UK Firms
}

\author{
Sanjay Kallapur* \\ Purdue University \\ And \\ University of California, Irvine \\ skallapu@uci.edu \\ Phone: (949) 824-1279 \\ Sabrina Kwan \\ Hong Kong University of Science and Technology \\ acskwan@ust.hk \\ Phone: (852) 2358-7566 \\ Fax: (852) 2358-1693
}

December 2002

${ }^{*}$ Corresponding author.

We thank Ashiq Ali, Mary Barth, Kevin Chen, Kay Stice, T. J. Wong, and seminar participants at the Hong Kong University of Science and Technology and Purdue University for useful comments. Sanjay Kallapur thanks the Center for International Business Education and Research at Purdue University for financial support. 


\title{
The Value Relevance and Reliability of Brand Assets Recognized by UK Firms
}

\begin{abstract}
We examine the value relevance and reliability of brand assets recognized by 33 UK firms, and the stock price reaction to the announcement of brand capitalization. We find that brand assets are value relevant, i.e., associated with market values. However, the market capitalization rates of brands of firms with low contracting incentives-firms with no transactions that avoided the London Stock Exchange (LSE) rule requiring shareholder approval for acquisitions/disposals, and firms with industry-adjusted leverage below the sample median - are higher than those of firms with high contracting incentives. Thus there could be substantial differences in the extent of bias or error in brand valuations of firms with different levels of contracting incentives, i.e., brand asset measures might not be reliable. The stock price reaction during the 21 days surrounding the first announcement of brand recognition has a significantly positive association with the recognized brand amount. However, the brand coefficient is only a small fraction of the reaction that would be expected if markets did not impute any value to brands before firms recognized them. Few previous value-relevance studies have examined intangible assets recognized in financial statements, and none have examined the effects of contracting incentives on the reliability of intangible assets.
\end{abstract}

Key Words: brand assets, intangible assets, contracting incentives, value relevance, and reliability.

JEL Classification Codes: M4.

Data Availability: The data are available from public sources identified in the text. 


\section{The Value Relevance and Reliability of Brand Assets Recognized by UK Firms}

\section{Introduction}

Previous studies, including one on brands (Barth et al. 1998b), find that intangible assets are value relevant (see Holthausen and Watts, 2001, 21, and their Table 1 which lists eight value-relevance studies on intangible assets). The intangible assets examined in these studies (except Barth and Clinch, 1998, who examine Australian firms' revaluations of both tangible and intangible assets) were not recognized in the financial statements. Rather, the asset measures were constructed by researchers or other outside parties who, unlike managers, do not have contracting incentives to bias their valuations.

Our study adds to the literature by examining the relevance and reliability of brands recognized on the balance sheets of 33 UK firms beginning in 1985. Brand asset measurement in our sample is subject to managerial discretion — the sample firms acquired brands not in isolation but instead as part of a business acquisition, and valued them separately from goodwill. We examine three research questions. One, are recognized brand asset measures value relevant? Two, do the market capitalization rates of brand assets differ for firms that have high and low incentives to bias the recognized brand amounts? Three, did the news of brand capitalization convey information to stock markets?

Regressing market values on brand assets, with book values of net non-brand assets, net income, and fixed year- and firm-effects as control variables, we find a positive $(+1.24)$ and significant (at better than the 1 percent level) coefficient on brand assets. Our sample consists of 232 firm-year observations of the 33 brand capitalizing 
firms during the 1984-1998 period. As do previous studies (see Barth et al., 2001), we interpret a significant coefficient to mean that managers' brand valuations are relevant and at least to some degree reliable.

By showing the value relevance of a recognized intangible asset we address one of Holthausen and Watts's (2001) criticisms of existing value-relevance studies that examine outsiders' valuations. They point out that managers have incentives to bias recognized amounts because of incentives relating to contracts such as bonus plans, compensation based on stock price which could be temporarily affected by managerial mis-statements, or debt covenants. Therefore, Holthausen and Watts (2001) argue, an asset measure that was value relevant when it was merely disclosed could cease to become value relevant when recognized. Contracting incentives are likely to be strong in our setting because brand assets are a substantial fraction of net assets: the median firm's brand assets are 44.2 percent of book value of equity (including brands). Also, brand accounting was regarded as controversial. ${ }^{1}$ We find that brands are value-relevant despite these reasons to expect that lack of reliability might overwhelm relevance.

Although value relevance implies that brand asset measures are not totally unreliable, we also perform a stronger test of reliability by investigating differences in brand capitalization rates of firms with strong and weak contracting incentives. If firms with high contracting incentives overvalue brands or introduce greater noise (as Holthausen and Watts, 2001, 29, argue) then their brand capitalization rates should be

\footnotetext{
${ }^{1}$ Farquhar, Han, and Ijiri (1992) quote a statement by the chairman of Britain's Accounting Standards Committee that brand accounting was the major accounting controversy of the last twenty years. Smith (1996) includes it among controversial accounting practices. A London Business School study commissioned by the Institute of Chartered Accountants in England and Wales (Barwise et al. 1989, 78) concludes that the problems facing brand valuation, including subjectivity and lack of precision, are "too intractable to produce useful and meaningful numbers."
} 
lower. Predictable differences in valuation biases or noise would suggest a lack of consensus, violating verifiability, a component of reliability. ${ }^{2}$ We base our measures of contracting incentives on Mather and Peasnell's (1991) and Muller's (1999) findings that brand recognition helped firms avoid London Stock Exchange (LSE) rules requiring shareholder approval for certain transactions, and reduce their leverage. ${ }^{3}$ We thus partition our sample into subsamples according to (1) whether or not the firm was affected by the LSE rule requiring shareholder approval for large acquisitions/disposals, and (2) whether the industry-adjusted debt-to-book-equity ratio was above or below the median.

Regressing market values on book values, net incomes, brand assets, the variables interacted with a dummy variable based on the LSE rule, and firm- and year-effects, we find that the brand coefficients for firms with high and low incentives to overstate brands are 0.35 and 1.94 respectively. Similarly, we find that brand coefficients for high- and low-leverage firms are 0.40 and 1.91. In each regression the difference between brand capitalization rates of firms with low and high incentives $(1.94-0.35=1.59$ and $1.91-$ $0.40=1.51$ respectively) is statistically significant, while the brand coefficient for firms with high contracting incentives to overstate brands ( 0.35 and 0.40 respectively) is insignificant. These findings suggest that managers' discretionary valuations of intangible assets recognized in financial statements might not be reliable. However, given the

\footnotetext{
${ }^{2}$ Statement of Financial Accounting Concepts (SFAC) 2: Qualitative Characteristics of Accounting Information (1980) defines verifiability as "the ability through consensus among measurers to ensure that information represents what it purports to represent or that the chosen method of measurement has been used without error or bias." Differences in error and bias among different groups of firms would therefore signify a lack of verifiability. Besides verifiability, SFAC 2 mentions representational faithfulness and neutrality as the other components of reliability.

${ }^{3}$ These studies, however, do not provide any evidence on value relevance or on whether these contracting incentives affect the market capitalization rates of the recognized amounts, the central questions in this study.
} 
differences in market capitalization rates, the markets do seem capable of seeing through the differences in reliability--our findings therefore do not suggest that markets are misled by the lack of reliability.

It is possible on the other hand that markets are misled by non-recognition of brands, i.e., they undervalue brand-intensive firms in the absence of disclosure or recognition of brand asset values. If so, the news of brand recognition should convey information to stock markets. We find that announcements of brand capitalization indeed result in positive abnormal returns on average equaling 12 percent of the value of the brands deflated by market value. Besides undervaluation, the benefits of relaxing contracting constraints can also explain the positive return. Although we attempt to distinguish between the two possible explanations by examining difference in abnormal returns to firms with high and low contracting incentives, we obtain insignificant coefficient differences; this prevents us from drawing any conclusions. Nevertheless, undervaluation, if any, is small in magnitude--the 0.12 coefficient is much lower than the brand capitalization rate we obtain in our value-relevance regression, 1.24, suggesting that most of the brand values had been capitalized into share prices before firms recognized them.

We are not aware of any study that examines the reliability of intangible assets, except those that find intangible assets to be value relevant and hence conclude that their measures are at least to some degree reliable. In other work on the value relevance of discretionary amounts recognized in financial statements, Aboody et al. (1999) examine the value relevance of upward revaluations of tangible fixed assets by UK firms, and examine the effect on value relevance of the debt-to-book-equity ratio. The difference in 
coefficients between high- and low-leverage firms in their study is lower than in our sample. A possible explanation for their smaller difference is that we study an intangible asset; such assets are generally considered to be more difficult to value (Barth and Landsman, 1995) and hence afford managers more discretion. Also, our sample firms' brand assets are a much higher fraction of book values of net assets, for the median firm 44.2 percent, than are revaluation reserves in Aboody et al.'s (1999) sample (6.5 percent). Our finding therefore indicates that large cross-sectional differences in market capitalization rates could be observed if valuations are subjective and contracting incentives are strong.

In contributing to the literature on value relevance and reliability of intangible assets, and more generally of recognized discretionary amounts, our findings also contribute to the policy debate on recognition of intangible assets. An article in Forbes (Stewart 2001), for example, opines that the existing accounting system that ignores selfgenerated intangible assets is like an octogenarian butler; although faithful, he has "lost track of some valuable jewels, paid no attention to the furnace and the water heater, and put the place at risk." The Economist (2001), on the other hand, argues that intangible assets cannot be reliably valued, and "soft measures, if required by the authorities, could end up being used to hoodwink investors." Also, responding to suggestions in "hundreds of recent articles, studies, and consultants' reports" (FASB, 2001, 2), in January 2002 the FASB added to its agenda a project on disclosure of self-generated intangible assets. The proposal (FASB, 2001) states that a secondary goal of the project is to take a step towards potential eventual recognition of the intangible assets. While our results should help standard setters by providing evidence of value relevance and suggesting problems with 
reliability, we do not draw explicit policy conclusions because the trade-off between relevance and reliability for standard setting is not precisely quantified (Barth et al. 2001, 81). Moreover, accounting standards are shaped by factors other than value relevance and reliability (Holthausen and Watts, 2001).

\section{Brand Accounting in UK, and Contracting Incentives}

UK company law and Statement of Standard Accounting Practice (SSAP) 14:

Group Accounts (1978) $)^{4}$ permit companies to recognize acquired as well as selfgenerated brands, trademarks and titles. The Companies Act 1985 allows intangible assets, including self-generated ones, other than goodwill, to be recognized at "current cost" (generally taken to be the lower of replacement cost or realizable value). SSAP 14 requires that the purchase price of a business acquisition be allocated to tangible assets and identifiable intangible assets other than goodwill on the basis of fair value to acquiror. Trademarks and publishing titles are cited as examples of identifiable intangible assets in the Companies Act 1985, SSAP 14, and SSAP 22: Accounting for Goodwill (1984).

Three of our 33 sample firms capitalized self-generated titles and brands (along with other acquired ones), ${ }^{5}$ but the other firms capitalized only brands obtained as part of a business acquisition. In either case managers have discretion in valuation-in the case of self-generated brands for determination of replacement costs and realizable values, and in the case of acquired brands for determination of fair values.

\footnotetext{
${ }^{4}$ SSAP 14 was superseded by the Financial Reporting Standard (FRS) 2: Accounting for subsidiary undertakings in 1992. FRS 2 does not change the relevant SSAP 14 provisions about allocation of the purchase price.

${ }_{5}^{5}$ Rank Hovis McDougall capitalized acquired and self-generated brands when it was subject to a takeover threat. The Telegraph and Goodhead also capitalized self-generated titles.
} 
Firms had contracting incentives to overstate brand assets in business acquisitions because any part of the acquisition price that was not allocated to tangible assets and identifiable intangible assets was instead allocated to goodwill (SSAP 22). Unlike in the USA, goodwill was immediately written off to owners' equity. Brands, on the other hand, were capitalized. Moreover, firms were not required to amortize brands except in case of value impairment. The difference in the treatment of goodwill versus brands gave firms an incentive to recognize brands separately from goodwill. ${ }^{6}$ Overstatement of brand assets would reduce the amount of goodwill written off to owners' equity, and thereby reduce the adverse effect on debt-to-book-equity ratios. ${ }^{7}$ This is an important contracting consideration because many UK firms have a provision in their charter prohibiting them from borrowing if it increases the debt-to-book-equity ratio beyond a certain limit. ${ }^{8} \mathrm{UK}$ banks also consider the debt-to-book-equity ratio in making their lending decisions (Citron 1992).

Another contracting motivation for brand capitalization was to avoid LSE constraints on large acquisition and disposal transactions. LSE listing rules require that

\footnotetext{
${ }^{6}$ In the US, APB Opinion 17: Intangible Assets (1970, paragraph 26, subsequently superceded by SFAS 142) required identifiable intangible assets to be recognized separately and SFAS 142: Goodwill and Other Intangible Assets, (2001, paragraphs B33-B35) requires firms to value separately any intangibles that either arise from contractual or other legal rights, or are separable. However, there is no difference in treatment of brands versus goodwill — under $A P B 17$ both were capitalized and amortized, and under SFAS 142 both are capitalized and need not be amortized, but must be tested for impairment. Also, in December 1997 the UK Accounting Standards Board issued Financial Reporting Standard (FRS) 10: Goodwill and Intangible Assets to replace SSAP 22. FRS 10 became effective on December 23, 1998. Similar to SFAS 142, it removes the distinction between goodwill and identifiable intangible assets by not requiring amortization of either kind of intangible asset if it has an indefinite life. From our sample we exclude observations with fiscal years ending on or after December 23, 1998. Thus brand asset measures in our sample are unaffected by changes in accounting standards.

${ }^{7}$ Although it recommended an immediate write-off, SSAP 22 (1984, paragraphs 32-35) permitted UK companies to capitalize goodwill, as in the USA. Because of the amortization requirement, and consequent reduction in future earnings, most companies preferred an immediate write-off. On Compustat Global Vantage we find only 155 firm-year observations with a non-zero goodwill asset, out of over 7,900 firmyear observations of UK firms between 1989 and 1997.

${ }^{8}$ In its 1989 annual report, Cadbury Schweppes plc, one of our sample firms, explicitly cited such a provision as a reason for capitalizing brands.
} 
companies obtain shareholders' approval for each "material” acquisition or disposal.

Although transactions are considered material if any one of five specified ratios ${ }^{9}$ exceeds

25 per cent, the binding constraint in the majority of cases is the ratio of total acquisition

price to the book value of net assets of the acquiring firm (Moorhouse, 1990). Firms

wishing to avoid the expense and delay associated with a shareholder vote ${ }^{10}$ in future

acquisitions or disposals therefore have an incentive to place a higher valuation on brand

assets rather than goodwill. Because goodwill is written off against equity, a higher

valuation on brand assets increases the book value of the firm's net assets; for a given

amount of acquisition/disposal consideration this reduces the consideration-to-assets ratio

and permits the firm to undertake larger acquisitions or disposals without seeking

shareholder approval. ${ }^{11}$

${ }^{9}$ The five ratios are:

1. The net assets of the acquired/disposed unit (hereafter target) divided by the book value of net assets of the acquiring/divesting firm (hereafter parent).

2. Net profits (before taxation and extraordinary items) attributable to the assets of the target divided by those of the parent.

3. The purchase/sale price divided by the book value of net assets of the parent.

4. The purchase/sale price divided by the market value of all the common shares of the parent.

5. The gross capital of the target divided by the gross capital of the parent. For the parent, gross capital is defined as the aggregate value of common shares (at market value immediately prior to announcement), preferred shares, debt (at market value, if listed), net current liabilities, and all other liabilities such as minority interests and deferred taxes. For the target, a similar aggregation is used except that the amount of the purchase/sale price is used instead of the market value of the common shares being acquired.

${ }^{10}$ The expenses include those related to holding an extraordinary general meeting to seek shareholder approval, professional advisory fees, and administrative expenses. For acquisitive companies, book equity depletion resulting from goodwill writeoffs means that shareholder approval is required for even small acquisitions. This process causes delay and is a 'deal breaker' in many potential acquisitions (KATO Communications, 1993, 143).

${ }^{11}$ A simple numerical example illustrates the benefit. Suppose XYZ company originally has $£ 100$ of assets and is all-equity financed. It acquires a company for $£ 50$ in cash. The tangible assets of the target have a fair value of $£ 20$. If the $£ 30(50-20)$ excess is entirely attributed to goodwill, XYZ's total assets and equity will equal $£ 70$ (assets $=100$ - cash paid, $50+$ tangible assets acquired, 20 ; owners' equity $=100$ goodwill write-off, 30 ). On the other hand, if $£ 10$ of the purchase price is allocated to brands, then goodwill would equal $£ 20$ ( 50 - tangible assets, 20 - brands, 10$)$. So total assets and equity will equal $£ 80$ (assets = 100 - cash paid, $50+$ tangible assets acquired, $20+$ brands, 10 ; equity $=100$ - goodwill write-off, 20). Subsequent to the acquisition if XYZ company wants to acquire another company for $£ 18$, it will have to seek shareholders permission in the first case where no brands were recognized (because 18/70 exceeds 25 percent), but not if brands had been recognized (because 18/80 does not exceed 25 percent). 
Mather and Peasnell (1991) and Muller (1999) find evidence that both contracting considerations motivated firms to capitalize brands. Muller measures the impact of LSE rules on firms by constructing a CLASSTEST variable representing the number of transactions that could avoid the LSE shareholder approval rules in the year subsequent to the first capitalization of brands. Although Muller finds in univariate tests that both leverage and CLASSTEST are associated with firms' decisions to capitalize brands, his multiple logit regression indicates that CLASSTEST is more significantly associated with brand capitalization, than is leverage.

\section{Sample and Descriptive Statistics}

Initially we used Extel Company Analysis (one of a family of databases, formerly produced by Financial Times, of UK company financials, share prices, and news) to identify UK firms reporting intangible assets in excess of 1 percent of total assets. We determined the nature of the capitalized intangibles from firms' annual reports because brand values are not separately reported in available databases. ${ }^{12}$ We include 33 firms that capitalized brands or titles (such as newspaper or magazine titles) in our sample. ${ }^{13}$ The earliest instance of capitalization (of titles) was by Reed International in 1985. For the tests that follow, we hand-collected brand values from annual reports and obtained

\footnotetext{
${ }^{12}$ For example, Compustat's Global Vantage data item 82 records the value of all intangibles; no breakdown is given except for goodwill (item 93).

${ }^{13}$ Some firms give a single figure, without a break-down, for all intangibles including brands, patents, copyrights, licenses, know-how, etc. We exclude these cases to concentrate on the more controversial assets such as brands and titles. Firms that capitalized brands or titles acquired individually (not as part of an acquisition) are also excluded as the valuations are not subject to managers' discretion. Two firms which capitalized brands were excluded for the following reasons. At the first balance sheet date, one firm, Mirror Group Newspaper plc, was under investigation for serious financial and pension fraud and its shares were suspended from trading over an extended period of time. Another firm, SmithKline Beecham, had a substantial portion of its equity in the form of overseas equity units and substantial price differences were documented between the two equity types (Frost and Pownall, 1996). The relationship between its market value, book value and brands is thus expected to be unrepresentative.
} 
stock prices and accounting data from Global Vantage's 1998 Industrial/Commercial File and Issue File, Extel Company Analysis, Extel Company Research, Extel Equity Research, and Microview.

In Table 1 we present a list of the brand-capitalizing firms. The capitalized brands form a substantial percentage of book values of equity for the sample firms--the percentage ranges from a low of 1.4 percent to a high of 293.2 percent (median 44.2 percent). When brand assets are subtracted from book values of equity, the median sample firm's leverage is 1.95 . It decreases substantially, to 1.16 when we include brands in book values. Market-to-book values of the median sample firms are similarly 5.19 and 2.50 without and with brands. Thus the brand assets of the sample firms are significant in comparison to book values of equity and debt; sample firms are therefore expected to have strong incentives to overvalue brands.

\section{[Table 1]}

We examined financial statements to determine the sample firms' policies on brand assets (not reported in any table). The basis of valuation is "cost [at acquisition]," "historical cost," or "fair value on acquisition" in most cases. The remaining firms mention "valuation," “directors' valuation," "fair value," or "use value" as the basis. However, very few firms provide details about the methods or assumptions used in the valuation. Only three firms amortized the brand assets. Yet brand assets do change over time, primarily because of acquisitions and disposals. Descriptive statistics presented in Table 2 show that the coefficient of variation of brands exceeds 10 percent for 20 of the 33 firms. Of the remaining 13, one firm has only a single observation, and six others have no variation in brands. The coefficient of variation of brands is generally increasing with 
the number of observations; the six firms with no brand variation have only 20 firm-year observations in total.

[Table 2]

\section{Research Design and Findings}

\section{Value Relevance of Brand Assets}

Following previous work (see Barth et al., 2001) we test the value relevance of brand assets by regressing market value of equity on year- and firm-effects, book value of equity (excluding brands), net income, and brand assets using pooled annual time-series and cross-sectional data for all sample firm-years. This regression specification is consistent with the model developed by Ohlson (1995), who shows that it is equivalent to the discounted dividends model under clean surplus accounting, ${ }^{14}$ if abnormal earnings follow an auto-regressive process. We thus estimate the following regression:

$$
\begin{gathered}
M V E_{j t}=\sum_{Y=84}^{98} a_{0 Y} Y R D U M_{Y}+\sum_{j=1}^{32} a_{1 j} F_{I R M_{j}}+a_{2} B V E_{j t}+a_{3} N I_{j t}+ \\
a_{4} B R A N D_{j t}+e_{j t},
\end{gathered}
$$

where

$$
\begin{array}{ll}
M V E & =\text { market value of equity, } \\
Y R D U M_{Y} & =1 \text { if year }=Y, \text { and } 0 \text { otherwise, } \\
F I R M_{j} & =1 \text { for observations pertaining to } j \text { th firm, and } 0 \text { for others, } \\
B V E & =\text { book value of equity (excluding brands), } \\
\text { NI } & =\text { net income, and } \\
B R A N D & =\text { brand assets. }
\end{array}
$$

\footnotetext{
${ }^{14}$ Although clean surplus does not hold in the UK because goodwill is written off directly to owners' equity, Stark (1997) shows analytically that dirty surplus elements can be tolerated in the Ohlson framework if they have no ability to predict future earnings, dividend, or book value. O'Hanlon and Pope (1999) show that dirty surplus elements in the UK are not value-relevant, thus making it unlikely that they predict future earnings or dividends or book value. The absence of clean surplus is therefore unlikely to affect our results. In any case, following previous studies such as Barth et al. (1998a), we do not rely on the Ohlson framework for our predictions because of its restrictive assumptions such as linear information dynamics.
} 
We use net income after extraordinary items because FRS 3: Reporting Financial Performance, effective June 22, 1993, effectively outlawed extraordinary items. Net income before extraordinary items is therefore inconsistent before and after $1993 .{ }^{15} \mathrm{~A}$ significantly positive coefficient $a_{4}$ indicates that brand assets are associated with market values after controlling for book value and net income. As in other value-relevance studies, we interpret an association as indicating value relevance and at least some degree of reliability (Barth et al., 2001, 81).

We include year dummies to control for fixed year-effects, e.g., effects of macroeconomic factors on stock prices. If correlated with the independent variables, these effects could otherwise bias the regression coefficients. Even if uncorrelated, the effects could bias the t-statistics by inducing contemporaneous cross-correlation of residuals. Similarly, we include fixed firm effects to control for any omitted variables that are firm-specific (i.e., constant over time) and for cross-correlation among residuals for the same firm. The use of panel data allows us to include both year- and firm-effects, thereby enabling us to mitigate bias in coefficients as well as standard errors.

Barth and Kallapur (1996) show that scale effects likely do not bias the coefficient of interest in cases such as the present one because $B V E$ and $N I$ are likely more highly correlated with scale than is $B R A N D$. Moreover, they show that in some cases deflation worsens bias, so we use undeflated variables in our regression. We use all firm-years beginning with the first year of each firm's brand capitalization, and ending on or before December 22, 1998, the day before the effective date of a new accounting standard on intangible assets, Financial Reporting Standard 10. This results in a sample 
of 232 observations. We delete five outliers identified using the DFBETAS statistic proposed by Belsley, Kuh, and Welsch (1980). ${ }^{16}$

[Table 3]

Panel A of Table 3 presents correlations among the dependent and independent variables used in the regressions. Although correlations among $B V E, N I$, and $B R A N D$ are high and significant, condition indexes in the regression estimation (not reported in the table) are below 10 and thus multi-collinearity does not affect regression coefficients (Belsley et al., 1980). BRAND is more highly correlated with $N I$ than with $B V E$; this is consistent with some of the brand value being reflected in profitability. Results of estimating regression equation (1) presented in Panel B of Table 3 show that the coefficient on $B R A N D$ is positive $(+1.24)$ and significant at better than the 1 percent level; brands are thus value relevant despite firms' incentives to overvalue them.

In our specification it is difficult to compare the brand coefficient with that on $B V E$ because variation in $B V E$ at the firm level is likely to be low; the fixed firm effects might therefore capture much of the effect of $B V E$. Indeed, if we omit firm effects then the coefficient on $B V E$ increases to 0.83 and is significant. Therefore, we do not draw conclusions from the insignificance of $B V E$. The problem is less likely with $N I$, even though the coefficient on $N I$ also is lower than when we drop firm fixed effects.

A coefficient value exceeding 1 on $B R A N D$ would seem to indicate that firms on average understate brands. This is consistent with the fact that the leading brand valuation

\footnotetext{
${ }^{15}$ We also estimated all our regressions using only data for fiscal years ending before June 22, 1993 (119 observations on 25 firms) and our results were qualitatively unchanged.

${ }^{16}$ In this and subsequent regressions we eliminate observations that have a DFBETAS exceeding 1 in absolute value for any regression coefficient. We also estimate the regressions after deleting observations that have DFBETAS exceeding $3 / \sqrt{ }$ (nobs), as recommended by Belsley, Kuh, and Welsch. This results in the deletion of 29 to 34 observations in the different regressions, but leaves the results qualitatively unchanged.
} 
method, developed by the consulting firm Interbrand and used by many of our sample firms, capitalizes current excess profits using a multiple that is determined based on a judgmental assessment of the brand's strength (Birkin, 1993). Potential profits from future sales growth and new products that may be launched under existing brand names are ignored in brand valuation, which could result in an understatement of brand values relative to those capitalized by the market. A coefficient exceeding 1 on brand assets is also consistent with Jennings et al.'s (1996) findings related to goodwill. An alternative explanation that we cannot rule out is that the coefficient is affected by correlated omitted variables. We believe, however, that omitted variables are less likely because, as previously mentioned, we control for omitted variables using fixed year- and firm-effects. We also report below that the brand coefficient is largely unchanged when we control for the effects of variables such as riskiness, growth, and persistence on NI and BVE.

We checked the robustness of our results using several alternative specifications described below. First, we perform a randomization test for the purpose of checking whether sample firms' brands and market values are mechanically related given that both are large in relation to book values. We regress actual market values on randomly generated brand values and the control variables used before--actual year- and firmeffects, book values, and net income. Consistent with the test's purpose, we generate random brand values such that the distribution of the ratio of random brand values divided by the excess of market value over book value (brand ratio) is the same as its actual sample distribution. We do this by randomly shuffling the brand ratios and then converting randomized brand ratios into random brand values. For example, Reed International's brands, book value of non-brand assets, and market value for the year 
ending on 3/31/1985 are $106.2,542.9$, and 664.2 respectively. Its brand ratio therefore equals 106.2/(664.2 - 542.9) $=0.88$. Similarly, Grand Metropolitan's brands, book value, and market value for 1988 are 588.3, 2818.7, and 4266.9 respectively. If Reed's 1985 brand ratio is randomly assigned to Grand Metropolitan for 1988 then Grand Metropolitan's randomized brand value used instead of its actual brand value in the regression is $0.88 *(4266.9-2818.7)=1274.4$. We perform 100 randomization trials using random brand values instead of the actual ones. The randomized p-value (not reported in any table) is 0.00 ; none of the brand coefficients in the randomized regressions exceed the actual coefficient. We thus reject the explanation that the significance of brands is a mechanical relation. However, because our sample brand values are large in relation to book values of equity, our findings may not generalize to firms whose brands values are small.

Second, previous research finds evidence that the coefficients on $B V E$ and $N I$ vary as functions of earnings persistence and riskiness. Variables used to proxy for these factors include: persistence of abnormal earnings (estimated in Dechow et al., 1999, using an AR(1) model), return on equity (Burgstahler and Dichev, 1997), standard deviation of monthly stock returns, and size, i.e., book value of total assets (Barth et al., 1998a). We create a dummy variable partitioning the sample firm-years into two groups based on persistence (estimated by an AR(1) model using the time series of each firm's abnormal earnings during the sample period), and re-estimate regression equation (1) allowing the intercept and coefficients on $B V E$ and $N I$ to vary with persistence. We similarly re-estimate regression equation (1) with dummy variables for each of the other factors. We also estimate a model with dummies for all the control variables described 
above, and their interactions with $B V E$ and $N I$, jointly included in the regression equations. The coefficient on $B R A N D$ is significant in each of these cases at the 1 percent level or better. Also, the brand coefficient remains above 1-it ranges from 1.12 to 1.36. Third, we controlled for sales growth rates because brand assets might proxy for them — managers and outside appraisers might be more comfortable justifying high brand values when sales growth is high. The results remain similar. Overall, the results of the sensitivity analysis reinforce the conclusion that brand assets are value relevant.

\section{Reliability of Brand Assets}

The value relevance finding indicates that any bias or measurement error in brand valuation is not severe enough to eliminate its relevance. Nevertheless, the question of whether there are predictable differences in bias and measurement error is likely to be of importance to standard setters as these are features of reliability, a desirable characteristic of accounting numbers $(S F A C 2)$. To investigate this issue we estimate the market capitalization rates of brands (regression coefficient on $B R A N D$ ) of firms partitioned according to whether their contracting incentives were high or low. We interact the dummy variables representing contracting incentives with each of the independent variables (book value of equity, net income, and brand assets) to allow the coefficients on the independent variables to differ according to contracting incentives. We thus estimate the following regressions:

and

$$
\begin{gathered}
M V E_{j t}=\sum_{Y=84}^{98} b_{0 Y} \text { YRDUM }_{Y}+\sum_{j=1}^{32} b_{1 j} \text { FIRM }_{j}+b_{2} B V E_{j t}+b_{3} N_{j t}+b_{4} B R A N D_{j t}+ \\
b_{5} B V E^{*} D \_ \text {nocltest }_{j t}+b_{6} N I * D \_ \text {nocltest } t_{j t}+b_{7} B R A N D * D \_ \text {nocltest } t_{j t}+e_{j t}
\end{gathered}
$$

$$
\begin{aligned}
& M V E_{j t}=\sum_{Y=84}^{98} c_{0 Y} \text { YRDUM }_{Y}+\sum_{j=1}^{32} c_{1 j} \text { FIRM }_{j}+c_{2} B V E_{j t}+c_{3} N I_{j t}+c_{4} B R A N D_{j t}+ \\
& c_{5} B V E^{*} D \_ \text {lolevg }{ }_{j t}+c_{6} N I^{*} D \_ \text {lolevg }_{j t}+c_{7} B R A N D * D \_ \text {lolevg }_{j t}+e_{j t}
\end{aligned}
$$


where

MVE $\quad$ = market value of equity,

$Y R D U M_{Y} \quad=1$ if year $=Y$, and 0 otherwise,

FIRM $_{j} \quad=1$ for observations pertaining to $j$ th firm, and 0 for others,

$B V E=$ book value of equity (excluding brands),

$N I \quad=$ net income,

$B R A N D \quad=$ brand assets.

D_nocltest $\quad=$ a dummy variable equaling zero if brand capitalization enabled a firm to avoid the LSE rule regarding shareholder approval for one or more transactions during the year subsequent to capitalization (i.e., if CLASSTEST exceeds zero). A transaction is considered to have avoided the LSE rules if either the assets ratio (ratio of net assets of the acquired/disposed entity divided by the net assets of the parent firm) or the consideration ratio (net purchase consideration paid or received divided by the net assets of the parent firm) exceeds 25 percent without including brand assets, but both ratios are lower than 25 percent after including brands. We exclude any transactions with a consideration-to-market-capitalization ratio exceeding 25 percent because those transactions would need shareholder approval regardless of brand capitalization. Twelve of the 33 sample firms had transactions that avoided the LSE rules as a result of brand capitalization. $^{17}$

D_lolevg $\quad=$ a dummy variable for industry-adjusted leverage. The dummy equals 1 if the sample firm's industry-adjusted leverage in the first year of brand capitalization is below the sample median. Industry-adjusted leverage is total debt divided by book value of equity (without brands) of the sample firm minus median leverage of all firms in the same 3- or 4-digit UK SIC code. For the sake of consistency, we exclude intangible assets from book value of equity in calculating leverage for firms in the industry group.

Once firms have decided to capitalize brands they apply their chosen accounting

method consistently in future periods, instead of freshly deciding each period whether to capitalize brands. We therefore calculate each contracting-incentives dummy (based on CLASSTEST or leverage) at the firm level using information at the time of the first brand

\footnotetext{
${ }^{17}$ Our definition of CLASSTEST differs from Muller's (1999) in one respect. We count the actual number of transactions that could avoid shareholder approval requirements under the LSE rules as a result of brand capitalization. Because the amount of acquired brands that could have been recognized is unavailable for his control firms, Muller (1999) uses a less accurate measure- he counts the number of transactions with assets and consideration-to-asset ratios (before capitalized brands) greater than 25 percent without checking
} 
capitalization. Therefore all firm-year observations for a given firm $j$ have the same value of the contracting-incentives dummy.

Coefficient $b_{4}\left(c_{4}\right)$ measures the brand assets' market capitalization rate for firms with at least one acquisition/disposal transaction that avoided the LSE rules (highleverage firms), and $b_{7}\left(c_{7}\right)$ measures how this rate differs for firms without transactions that avoided the LSE rules (low-leverage firms). If there is an upward bias in brand measures of firms with greater contracting incentives, then the market capitalization rate for those firms' brands will be lower. In a regression context if an independent variable is multiplied by a constant $k,(>1$ for high-contracting-incentive firms because of upward bias) then the estimated coefficient for that group of firms equals the original coefficient divided by $k$, and hence is smaller.

In addition to bias, Holthausen and Watts $(2001,29)$ suggest that managers might also introduce noise to mislead auditors and stock markets. Such noise would lead to errors in brand measures, which would bias the estimated regression coefficient towards zero in a multiple regression if other regressors are measured without error (Garber and Klepper, 1980). Because the brand coefficient is expected to be positive, bias towards zero implies a smaller coefficient for firms with greater contracting incentives. Thus we expect both upward bias and greater error in brand measures to result in a smaller brand coefficient. ${ }^{18}$ Accordingly the brand coefficient for firms with lower contracting

whether these ratios are less than 25 percent after brand recognition. Like us, Muller excludes transactions with a consideration-to-market capitalization ratio exceeding 25 percent.

${ }^{18}$ The regression coefficient remains biased towards zero even if other variables are measured with error, as long as those errors are small (i.e., have low variance). On the other hand, if the error in measuring other variables is large, then the effect of measurement error on the coefficient could be opposite to that of the bias, weakening our ability to find the hypothesized results. 
incentives will be higher, and a positive value would be obtained for coefficients $b_{7}$ and $c_{7}$.

We include $B V E^{*} D \_n o c l t e s t$, and $N I^{*} D \_n o c l t e s t\left(B V E^{*} D \_l o l e v g\right.$, and $N I^{*} D \_$lolevg) to ensure that the estimated coefficient on $B R A N D * D \_$nocltest $\left(B R A N D * D \_l o l e v g\right)$ is unaffected by any association between stock prices and interactions of the contracting proxy with $B V E$ and $N I$. The firm dummies included in the regression are finer than the contracting proxy (whose value depends on whether an observation pertains to a firm that is classified into the high- or low-contractingincentives group). Therefore we do not include contracting proxies in the regressionthey would be collinear with some of the firm dummies if we did. In addition to the firm dummies, as in estimating regression equation (1), we include year dummies to capture fixed year effects. The sample, as before, consists of 232 firm-year observations. In each regression (equations 2 and 3) the DFBETAS statistic proposed by Belsley, Kuh, and Welsch (1980) results in deletion of two outliers.

[Table 4]

Panel A of Table 4 reports the correlations between the contracting dummies and the other regression variables. Although the CLASSTEST-based and leverage-based dummies are significantly correlated (0.36), the correlation is far from perfect; results based on the two proxies are therefore not merely repeated versions of each other. Results of estimating regression equations (2) and (3), reported in Panel B of Table 4, show that the coefficient on $B R A N D^{*} D \_$nocltest $\left(B R A N D^{*} D \_\right.$lolevg) is positive, $1.59(1.51)$, and significantly different from zero at $p<0.01$. The effective number of observations in each case - the number of observations with contracting- incentives dummy equal to 1 -is 153 
and 117 respectively for dummies based on CLASSTEST and leverage. The significant coefficient indicates that the market's brand capitalization rate for firms with lower contracting incentives to over-state brands (firms with no transactions that escaped the LSE requirements, or with low leverage) is higher than that for firms with higher contracting incentives. The coefficient on $B R A N D$ for firms with transactions that avoided the LSE rule (high leverage) is $0.35(0.40)$, and these values are not statistically significant. The market's capitalization rates for brand assets of firms with low contracting incentives are $1.94(0.35+1.59)$ and $1.91(0.40+1.51)$ in regressions $(2)$ and (3) respectively.

The point estimates of the coefficients therefore indicate that the brand capitalization rates for firms with lower contracting incentives are five to six times $(1.94 / 0.35=5.5$ and $1.91 / 040=4.8)$ the capitalization rates of firms with high contracting incentives. Thus the differences in brand capitalization rates of firms with high and low contracting incentives are statistically as well as economically significant, suggesting that brand asset measures might lack reliability. This conclusion is contrary to that in Barth and Clinch (1998) who find that discretionary revaluations of intangible assets in Australia are as value relevant as are revaluations of tangible assets. They, however, do not condition their analysis on contracting incentives - ours is therefore a stronger test of reliability.

Another study, Aboody et al. (1999), finds modest differences in value relevance of discretionary revaluations of tangible fixed assets in the UK depending on firms' debt to equity ratio - in regressions with stock price as the dependent variable, they find that the coefficient on the revaluation balance is 0.44 , and that on the revaluation balance 
interacted with the debt to book equity ratio is -0.02 . Aboody et al. (1999) use a continuous debt to equity ratio measure unlike the dummy we use. Nevertheless, we can estimate that the difference between the coefficients of high- and low-leverage firms in their sample is definitely below $0.10(0.02 * 5)$--they report that the debt to book equity ratio does not exceed 5 for any firm. The 0.10 coefficient is smaller than in our study (1.51) in absolute as well as in relative terms $(0.10 / 0.44$ versus $1.51 / 1.91)$. One possible reason is that we examine the value relevance of an intangible asset; these assets are generally considered to be more difficult to value (Barth and Landsman, 1995) and hence afford managers more discretion. Second, the median firm's revaluation reserves are only 6.5 percent of book values in their sample while the median firm's brand assets are 44.2 percent of book values in ours. Our finding therefore adds to the literature by showing that large cross-sectional differences in market capitalization rates could be observed if valuations are subjective and contracting incentives are strong.

The coefficients 0.35 and 0.40 on BRAND in regressions (2) and (3) are statistically insignificant at conventional levels. This is consistent with lack of reliability overwhelming their value relevance. However, because the sample sizes are relatively small, we do not draw conclusions from insignificant coefficients.

One potential problem with the use of the $D \_n o c l t e s t$ variable is that errors in brand valuation could affect whether the firm subsequently avoids the LSE requirements. That is, if firms' brand valuations are unbiased but have some error, firms with positive valuation error (over-valuers) will have lower brand capitalization rates (if markets undo the effects of the error) and be more likely to avoid the LSE requirements in the future. Thus the finding of lower brand capitalization rates for firms with $D \_$nocltest $=0$ could 
be attributable to valuation errors rather than contracting incentives. The small and insignificant correlation between $D \_n o c l t e s t$ and $B R A N D(0.03$, reported in Panel A of Table 4) casts doubt on the validity of this explanation. Nevertheless, in another attempt to rule out this explanation ${ }^{19}$ we use an alternative measure for CLASSTEST, namely whether the firm needed shareholder approval for any acquisition during the year prior to the date of the balance sheet in which brands were first capitalized. This measure proxies for the probability of a firm being subject to the LSE requirements in future, assuming that past acquisitions are good indicators of future acquisitions. Specifically we define $D_{-}$nocltest $_{0}=1$ if the firm had no transactions that required shareholder approval under the LSE rules during the year ending on the date of the first balance sheet containing capitalized brands. The coefficient $B R A N D^{*} D_{-}$nocltest $t_{0}$ remains significant at better than the 1 percent level using this alternative specification.

Our findings regarding the significance of coefficients on $B R A N D * D \_n o c l t e s t$, and $B R A N D^{*} D \_$lolevg are largely unaffected when we perform the robustness tests described for the unpartitioned sample. There is however, one exception: the randomization p-values are 0.15 and $0.14 .^{20}$ Our finding that brand capitalization rates of firms with high and low contracting incentives differ must therefore be interpreted with caution. Besides, our findings are based on market capitalization rates and therefore do not indicate that markets are misled by the lack of reliability.

\footnotetext{
${ }^{19} \mathrm{We}$ measure leverage using book value of equity excluding brands; the leverage-based contracting incentive measure is therefore unaffected by this problem.

${ }^{20}$ The purpose of the regression equations is to assess whether the brand coefficient differs according to contracting incentives. Accordingly for the randomization test we randomly assign firms to $D \_$nocltest $=0$ and $D \_$nocltest $=1$ categories, and leave other variables unchanged (similalrly for $D \_l o l e v g$ ).
} 


\section{Stock Price Effects of Brand Recognition}

Although markets may not be misled by lack of reliability, previous evidence suggests that markets undervalue intangible-asset-intensive firms in the absence of recognition (Aboody and Lev 2000; Chan et al. 2000; Lev et al. 2000, Lev 2001). Lev et al. (2000) and Chan et al. (2000) find positive risk-adjusted returns to portfolios of stocks of firms with high $R \& D$ growth rates and high $R \& D$-to-market-value ratios respectively. Aboody and Lev (2000) find that trades by insiders in R\&D-intensive firms are three to four times as profitable as are trades by insiders in non-R\&D-intensive firms, thus suggesting greater information asymmetries in R\&D-intensive firms.

In case of brands, undervaluation could result because markets impute conservative brand valuations to all firms in the absence of disclosure. Alternatively markets could be unbiased on average, and firms whose brands are undervalued could selectively resort to brand recognition to signal their true values. In either case, undervaluation before recognition is consistent with firms overcoming information asymmetries through brand recognition.

If brands were undervalued before firms recognized them, then news of brand recognition must convey positive information to markets. Besides undervaluation, positive information content could also be explained by the benefit to firms of having relaxed contracting constraints. On the other hand, Smith (1996) considers brand capitalization a controversial accounting practice and its use a signal of an underlying weakness in the firm's financial position. If markets interpret brand capitalization as such then we should observe a negative stock price reaction to the news of brand capitalization. 
We could estimate the market reaction for only 24 of the 33 sample firms: for six firms the earliest announcement was before its stock was publicly traded, for two firms the stocks were newly listed and previous returns for estimating the market model are not available, and in one other case we could not determine the date of earliest announcement of brand values. To determine the market reaction to brand announcements we regress market-and-risk-adjusted abnormal returns (estimated using market model betas calculated over the 60 days ending 30 days before the event date) on BRAND/MVE. Our specification is as follows:

$$
A R_{j t}=d_{0}+d_{1}\left(B R A N D_{j t} / M V E_{j, t-1}\right)+e_{j t}
$$

where

$$
\begin{aligned}
A R_{j t}= & \text { announcement period (days }-10 \text { to }+10)^{21} \text { abnormal returns for the } j \text { th firm } \\
& \text { in year } t \text { (estimated as the difference between actual returns and expected } \\
& \text { returns based on market model parameters estimated over the } 60 \text { trading } \\
& \text { days ending } 30 \text { days before the announcement). } \\
B R A N D_{j t}= & \text { brand assets at the end of year } t . \\
M V E_{j, t-1}= & \text { market value of equity at the end of year } t-1 .
\end{aligned}
$$

\section{[Table 5]}

Results presented in Table 5 show that the coefficient on BRAND/MVE is +0.12 and significant at better than the 1 percent level. ${ }^{22}$ The coefficient should equal that on $B R A N D$ in regression equation (1) if 10 days before news of brand capitalization the markets expected zero brand values, and did not receive news about any other variables during the 21-day returns accumulation period, ${ }^{23}$ under these assumptions regression

\footnotetext{
${ }^{21}$ Results for other announcement period such as days -2 to +1 and -5 to +5 were slightly weaker.

${ }^{22}$ A randomization test similar to the one for the value-relevance regression indicates that the coefficient on $B R A N D / M V E$ is significant at the 4 percent level. We randomly shuffled non-zero BRAND/MVE values, keeping all other variables unchanged.

${ }^{23}$ In fact, twelve of the 24 announcements were concurrent with earnings announcements. We conduct additional sensitivity tests by adjusting the abnormal returns for earnings levels and changes (following Easton and Harris, 1991) in these cases. We determine response coefficients on earnings levels and changes, required for the adjustment, by regressing abnormal returns on earnings levels and changes using
} 
equation (4) can be derived from regression equation (1) by first-differencing and deflating by market value. The comparison of coefficients, however, indicates that the 0.12 coefficient on BRAND/MVE in regression equation (4) is much lower than the 1.24 coefficient on BRAND in regression equation (1). Thus the market had already capitalized all but 10 percent $(=0.12 / 1.24)$ of the brand values into prices before brands were actually capitalized by firms. Thus undervaluation of brands, if any, is small in economic magnitude.

The significantly positive return to news of brand capitalization is consistent with either undervaluation or the benefit to firms from relaxing contracting constraints through brand capitalization; it is inconsistent with brand recognition being interpreted as a signal of weakness. To evaluate the constraint relaxation explanation, we interact $B R A N D / M V E$ with contracting dummies ( $D \_n o c l t e s t$ or $\left.D \_l o l e v g\right)$ and include the interaction term in the regression, as follows.

$$
\begin{aligned}
A R_{j t}= & f_{0}+f_{1}\left(B R A N D_{j t} / M V E_{j, t-1}\right)+f_{2} D_{-} \text {nocltest }+ \\
& f_{3}\left(B R A N D_{j t} / M V E_{j, t-1} * D_{-} \text {nocltest }\right)+e_{j t}, \\
\text { and } & \\
A R_{j t}= & g_{0}+g_{1}\left(B R A N D_{j t} / M V E_{j, t-1}\right)+g_{2} D_{-} \text {lolevg }+ \\
& g_{3}\left(B R A N D_{j t} / M V E_{j, t-1} * D_{-} \text {lolevg }\right)+e_{j t} .
\end{aligned}
$$

where all variables are as defined before.

Results presented in Table 5 show that the coefficients on $B R A N D / M V E *$ D_nocltest and BRAND/MVE $*$ D_lolevg, 0.21 and -0.00 do not differ significantly from zero; the contracting constraint relaxation explanation predicts positive coefficients. Because of their insignificance we are unable to distinguish between the two possible explanations for positive returns at the announcement of brand capitalization. Thus we

pooled cross-section and time-series data for all available years for the 12 firms. Our results are similar to 
cannot rule out undervaluation of brands, but as argued above, the magnitude of undervaluation is small.

\section{Conclusions}

This study examines the value relevance and reliability of brand assets recognized by 33 UK firms beginning in 1985. Most previous studies on the value relevance of intangible assets have examined valuations of outside parties rather than managers who could be subject to contracting incentives to bias recognized amounts. The only other study that examines recognized intangible assets, Barth and Clinch (1998), does not examine the effects of contracting incentives on value relevance. Also, previous studies on brand recognition in the UK (e.g., Muller, 1999) have examined the incentives for brand recognition, but not the effects of these incentives on the value relevance and reliability of the recognized brand values.

Our results suggest that recognized brand values are value relevant despite managers' incentives to over-value them. These findings are robust to several sensitivity tests. However, market capitalization rates of brands of firms with low contracting incentives--firms with no transactions that avoided the LSE rules requiring shareholder approval for acquisitions/disposals, and firms with industry-adjusted leverage below the sample median--are substantially higher than those of firms with high contracting incentives. The difference in market capitalization rates indicates differences in the amount of bias or error in brand valuations of different groups of firms, suggesting that brand asset measures lack reliability. These results must however be interpreted with 
caution because in a randomization test we perform for sensitivity analysis, the differences are significant at only the 15 and 14 percent levels. Another caveat is that our findings are based on market capitalization rates; they therefore do not indicate that markets are misled by the lack of reliability.

Previous studies that investigate the effects of contracting incentives on the value relevance of managers' discretionary valuations, e.g., Aboody et al. (1999), which examines managers' revaluations of tangible fixed assets, find much smaller differences in capitalization rates. Brand assets in our sample are higher as a proportion of total assets than is the revaluation balance in Aboody et al.'s sample. Besides, valuation of intangible assets like brands is likely subject to greater discretion. Subject to caveats mentioned before, our study therefore contributes to the literature by showing that substantial differences in market capitalization rates of recognized assets could be observed for different groups of firms when contracting incentives are strong, and the valuations are subjective.

We also find a significantly positive association between market returns during the 21-day period surrounding the first announcement of brand asset values. The positive association could result either from undervaluation of brands by markets prior to recognition, as suggested by Lev (2001), or from the relaxation of contracting constraints. Although we attempt to distinguish between the two explanations for a positive association, insignificant coefficients prevent us from doing so. We are thus unable to rule out the undervaluation explanation, but the magnitude of undervaluation is small.

By examining the value relevance and reliability of intangible assets, our evidence contributes to the policy debate on recognition of intangible assets. We, however, do not 
draw any policy conclusions because our evidence suggests relevance as well as a possible lack of reliability, and the trade-off between these considerations is not precisely quantified (Barth et al., 2001). Besides, accounting standards are shaped by factors other than value relevance and reliability (Holthausen and Watts, 2001). 


\section{REFERENCES}

Aboody, D., Barth, M., and Kasznik, R., 1999. Revaluations of fixed assets and future firm performance: Evidence from the UK. Journal of Accounting and Economics $26,149-178$.

Aboody, D., and B. Lev. 2000. Information Asymmetry, R\&D, and Insider Gains. Journal of Finance (LV), 2747-2766.

Barth, M., Beaver, W., and Landsman, W., 1998a. Relative valuation roles of equity book value and net income as a function of financial health. Journal of Accounting and Economics 25, 1-34.

Barth, M., Beaver, W., and Landsman, W., 2001. The relevance of the value relevance literature for financial accounting standard setting: Another view. Journal of Accounting and Economics 31(1-3): 77-104.

Barth, M., Clement, M., Foster, G., and Kasznik, R., 1998b. Brand Values and Capital Market Valuation. Review of Accounting Studies 3, 41-68.

Barth, M., and Clinch, G., 1998. Revalued financial, tangible, and intangible assets: Associations with share prices and non market-based estimates. Journal of Accounting Research 36, 199-233.

Barth, M., and Kallapur, S., 1996. The effects of cross-sectional scale differences on regression results in empirical accounting research. Contemporary Accounting Research, 527-567.

Barth, M., and Landsman, W., 1995. Fundamental issues related to using fair value accounting for financial reporting. Accounting Horizons 9:4, 97-107. 
Barwise, P., Higson, C., Likierman, A., and Marsh, P., 1989. Accounting for Brands. London Business School and the Institute of Chartered Accountants in England and Wales, London, U.K.

Belsley, D. A., Kuh, E., and Welsch, R. E., 1980. Regression Diagnostics. John Wiley \& Sons, Inc., New York, NY.

Birkin, M. 1993. Interbrand: The valuation of trade marks and brand names. In Accounting for Brands. KATO Communications, London, U.K.: Financial Times Business Information.

Burgstahler, D., and Dichev, I., 1997. Earnings, adaptation, and equity value. The Accounting Review 72, 187-215.

Chan, L., J. Lakonishok and T. Sougiannis, 2000. The Stock Market Valuation of Research and Development Expenditures. Working Paper. University of Illinois.

Citron, D.B. 1992. Accounting measurement rules in UK bank loan contracts. Accounting and Business Research 23, 21-30.

Dechow, P., Hutton, A., and Sloan, R., 1999. An empirical assessment of the residual income model. Journal of Accounting and Economics 26, 1-34.

Easton, P. D., and T. Harris, 1991. Earnings as an Explanatory Variable for Returns. Journal of Accounting Research 29(1): 19-36.

The Economist, 2001. Touchy-feely. (5/17/01).

Farquhar, P., Han, J., and Ijiri, Y., 1992. Brands on the balance sheet. Marketing Management, Winter, 16-22. 
Financial Accounting Standards Board (FASB), 2001. Proposal for a new agenda project: Disclosure of information about intangible assets not recognized in financial statements.

Frost, C., and G. Pownall, 1996. Interdependencies in the global markets for capital and information: The case of Smithkline Beecham plc. Accounting Horizons 10.1:3857.

Garber, S., and Klepper, S., 1980. Extending the classical normal errors-in-variables model. Econometrica 48(6), 1541-1546.

Holthausen, R. W., and Watts, R. L., 2001. The relevance of the value relevance literature for financial accounting standard setting. Journal of Accounting and Economics 31(1-3): 3-76.

Jennings, R, J. Robinson, R. Thompson II, and L. Duvall, 1996. The relation between accounting goodwill numbers and equity values. Journal of Business Finance \& Accounting 23(4): 513-533.

KATO Communications, 1993. Accounting for brands. Financial Times Business Information, London, U.K.

Lev, B., 2001. Intangibles: Management, Measurement, and Reporting. The Brookings Institution.

Lev, B., B. Sarath, and T. Sougiannis, 2000. R\&D Reporting Biases and Their Consequences. Working Paper, Stern School of Business, New York University. Mather, P.R., and Peasnell, K. V., 1991. An examination of the economic circumstances surrounding the decisions to capitalize brands. British Journal of Management 2, $151-164$. 
Moorhouse, M., 1990. The case for capitalising brands. In: Michael Power, eds., Brand and Goodwill Accounting Strategies. Woodhead-Faulkner, New York, NY.

Muller, K. A., 1999. An examination of the voluntary recognition of acquired brand names in the United Kingdom. Journal of Accounting and Economics 26, 179191.

O'Hanlon, J.F., and P. F. Pope, 1999. The value-relevance of UK dirty surplus accounting flows. British Accounting Review 32: 459-482.

Ohlson, J., 1995. Earnings, book values, and dividends in security valuation. Contemporary Accounting Research, 661-688.

Smith, T., 1996. Accounting for growth: Stripping the camouflage from company accounts. Century Business, London, U.K.

Stark, A. W., 1997. Linear information dynamics, dividend irrelevance, corporate valuation, and the clean surplus relationship. Acccounting and Business Research, Summer, 219-228.

Stewart, T. A., 2001. Accounting gets radical. Fortune (4/16/01). 


\section{Table 1}

\section{Descriptive Statistics for UK Firms Capitalizing Brands}

Earliest Brand Capitalization and Debt to Book Equity and Market to Book Ratios

\begin{tabular}{|c|c|c|c|c|c|c|}
\hline Firm Name & $\begin{array}{c}\text { First } \\
\text { balance } \\
\text { sheet date }^{\mathrm{a}}\end{array}$ & $\begin{array}{c}\text { Brands/ } \\
\text { BVE }\end{array}$ & $\begin{array}{c}\mathrm{D} / \mathrm{E} \\
\text { without } \\
\text { brands }\end{array}$ & $\begin{array}{c}\mathrm{D} / \mathrm{E} \\
\text { with } \\
\text { Brands }\end{array}$ & $\begin{array}{c}\text { MVE/BVE } \\
\text { without } \\
\text { brands }\end{array}$ & $\begin{array}{c}\text { MVE/BVE } \\
\text { With } \\
\text { brands }\end{array}$ \\
\hline Reed International & $3 / 31 / 85$ & $16.4 \%$ & 1.27 & 1.06 & 1.22 & 1.02 \\
\hline United Newspapers & $12 / 31 / 85$ & $98.2 \%$ & 130.96 & 2.42 & 160.88 & 2.97 \\
\hline Reckitt and Colman & $1 / 4 / 86$ & $14.5 \%$ & 1.10 & 0.94 & 2.93 & 2.50 \\
\hline Emap & $4 / 5 / 86$ & $17.6 \%$ & 1.00 & 0.82 & 4.60 & 3.79 \\
\hline London International & $3 / 31 / 88$ & $44.2 \%$ & 6.04 & 3.37 & 8.38 & 4.68 \\
\hline Adscene Group & $5 / 28 / 88$ & $60.1 \%$ & 4.42 & 1.76 & 9.02 & 3.60 \\
\hline Ranks Hovis McDougall & $9 / 3 / 88$ & $73.0 \%$ & 2.79 & 0.75 & 5.19 & 1.40 \\
\hline Grand Metropolitan & $9 / 30 / 88$ & $17.3 \%$ & 0.87 & 0.72 & 1.51 & 1.25 \\
\hline Lonrho & $9 / 30 / 88$ & $10.0 \%$ & 1.73 & 1.56 & 1.48 & 1.33 \\
\hline Guinness & $12 / 31 / 88$ & $48.2 \%$ & 1.29 & 0.67 & 2.01 & 1.04 \\
\hline Ladbroke & $12 / 31 / 88$ & $13.9 \%$ & 0.79 & 0.68 & 1.07 & 0.92 \\
\hline United Biscuits & $12 / 31 / 88$ & $20.7 \%$ & 1.89 & 1.50 & 2.96 & 2.34 \\
\hline WPP & $12 / 31 / 88$ & $293.2 \%$ & $(5.32)$ & 10.28 & $(1.92)$ & 3.71 \\
\hline Nu Swift & $12 / 31 / 88$ & $35.7 \%$ & 10.47 & 6.73 & 9.94 & 6.39 \\
\hline Sterling Publishing & $3 / 31 / 89$ & $58.5 \%$ & 6.65 & 2.76 & 16.74 & 6.95 \\
\hline Continuous Stationery & $3 / 31 / 89$ & $82.3 \%$ & 7.93 & 1.40 & 16.54 & 2.93 \\
\hline Southnews & $4 / 1 / 89$ & $70.6 \%$ & 4.00 & 1.17 & 19.99 & 5.87 \\
\hline Goodhead & $5 / 31 / 89$ & $37.5 \%$ & 1.95 & 1.22 & 2.23 & 1.39 \\
\hline Daily Mail \& General Trust & 9/30/89 & $47.7 \%$ & 3.42 & 1.79 & 3.43 & 1.79 \\
\hline Cadbury Schweppes & $12 / 30 / 89$ & $51.6 \%$ & 5.33 & 2.58 & 8.47 & 4.09 \\
\hline Jeyes Group & $12 / 30 / 89$ & $1.4 \%$ & 1.16 & 1.14 & 2.77 & 2.73 \\
\hline Trinity International & $12 / 29 / 90$ & $18.3 \%$ & 0.98 & 0.80 & 2.23 & 1.82 \\
\hline Blacks Leisure & 2/29/92 & $5.0 \%$ & 1.34 & 1.27 & 2.28 & 2.16 \\
\hline Telegraph & $12 / 31 / 92$ & $54.8 \%$ & 0.59 & 0.27 & 3.19 & 1.44 \\
\hline Matthew Clark & 4/30/93 & $37.6 \%$ & 0.65 & 0.40 & 2.52 & 1.57 \\
\hline Midland Indep. Newspapers & $12 / 31 / 94$ & $90.5 \%$ & 5.28 & 0.50 & 14.95 & 1.42 \\
\hline Dalgety & $6 / 30 / 95$ & $43.0 \%$ & 6.97 & 3.97 & 7.36 & 4.19 \\
\hline Johnston Press & $12 / 31 / 95$ & $43.7 \%$ & 2.34 & 1.32 & 10.05 & 5.65 \\
\hline Highland Distilleries & $8 / 31 / 96$ & $31.1 \%$ & 1.50 & 1.03 & 3.29 & 2.26 \\
\hline Scottish Radio Holdings & 9/30/96 & $55.6 \%$ & 1.67 & 0.74 & 10.86 & 4.82 \\
\hline Scottish Media Group & $12 / 31 / 96$ & $61.4 \%$ & 1.76 & 0.68 & 11.61 & 4.48 \\
\hline Charterhouse Comm. & $5 / 31 / 97$ & $131.8 \%$ & $(2.44)$ & 0.77 & $(5.48)$ & 1.74 \\
\hline Newsquest & $12 / 31 / 97$ & $156.7 \%$ & $(2.04)$ & 1.16 & $(4.56)$ & 2.59 \\
\hline MEDIAN & & $44.2 \%$ & $1.95^{\mathrm{b}}$ & 1.16 & $5.19^{\mathrm{b}}$ & 2.50 \\
\hline MEAN & & $55.8 \%$ & $7.27^{\mathrm{c}}$ & 1.76 & $11.66^{\mathrm{c}}$ & 2.94 \\
\hline
\end{tabular}




\section{Table 1 (continued)}

$\mathrm{D} / \mathrm{E}=$ Debt/Equity ratio $=$ Total Liabilities / Book Value of Shareholders' Equity

MVE = Market value of shareholders' equity

BVE = Book value of shareholders' equity (including brands, except where noted otherwise).

a For six firms share prices are not available at the date of the first balance sheet containing brand assets, because, e.g., they were not publicly listed at the time. For these firms we report the first balance sheet date with available share price information.

b Firms with negative leverage or MVE/BVE are treated as having the highest leverage or MVE/BVE.

c Excluding firms with negative book value of equity. 
Table 2

Descriptive Statistics

Number of Observations, and Mean, Standard Deviation, and Variation in Brand Values by Firm

\begin{tabular}{|c|c|c|c|c|c|c|}
\hline \multirow[b]{2}{*}{ Firm Name } & \multirow[b]{2}{*}{$\mathrm{N}$} & \multicolumn{5}{|c|}{ Brand Value } \\
\hline & & Mean & $\mathrm{SD}$ & $\mathrm{CV} \%$ & Min & Max \\
\hline Emap & 13 & 181.2 & 172.1 & 95.0 & 5.5 & 479.7 \\
\hline Reckitt and Colman & 13 & 615.0 & 470.9 & 76.6 & 55.8 & 1295.6 \\
\hline United Newspapers & 13 & 121.8 & 27.4 & 22.5 & 60.0 & 133.0 \\
\hline Adscene Group & 11 & 16.7 & 15.3 & 91.8 & 2.7 & 40.0 \\
\hline Southnews & 10 & 14.6 & 21.5 & 147.2 & 2.6 & 72.5 \\
\hline Sterling Publishing & 10 & 15.4 & 11.3 & 73.1 & 1.8 & 30.7 \\
\hline United Biscuits & 10 & 174.1 & 53.4 & 30.7 & 106.5 & 251.0 \\
\hline Daily Mail & 10 & 200.3 & 35.6 & 17.8 & 174.4 & 260.7 \\
\hline Ladbroke Group & 10 & 326.7 & 52.7 & 16.1 & 276.7 & 376.7 \\
\hline London International & 10 & 35.6 & 3.4 & 9.5 & 32.0 & 40.4 \\
\hline Cadbury Schweppes & 9 & 798.1 & 611.7 & 76.6 & 304.0 & 1689.0 \\
\hline Grand Metropolitan & 9 & 2660.4 & 965.1 & 36.3 & 588.3 & 3884.0 \\
\hline Jeyes Group & 9 & 0.5 & 0.2 & 32.0 & 0.2 & 0.7 \\
\hline Goodhead Group & 9 & 11.2 & 3.0 & 26.5 & 6.2 & 16.0 \\
\hline WPP & 9 & 330.6 & 58.3 & 17.6 & 175.0 & 350.0 \\
\hline Guinness & 9 & 1388.3 & 10.0 & 0.7 & 1375.0 & 1395.0 \\
\hline Trinity & 8 & 127.4 & 141.4 & 111.0 & 10.2 & 354.0 \\
\hline Reed International & 8 & 844.3 & 648.4 & 76.8 & 106.2 & 1669.7 \\
\hline Matthew Clark & 6 & 9.7 & 0.0 & 0.1 & 9.7 & 9.7 \\
\hline Ranks Hovis McDougall & 5 & 614.6 & 105.7 & 17.2 & 459.0 & 740.0 \\
\hline Nu Swift & 5 & 9.5 & 1.0 & 10.2 & 8.5 & 10.4 \\
\hline Blacks Leisure & 4 & 0.8 & 0.1 & 7.2 & 0.7 & 0.8 \\
\hline Continuous Stationery & 4 & 4.5 & 0.0 & 0.0 & 4.5 & 4.5 \\
\hline Lonrho & 4 & 117.0 & 0.0 & 0.0 & 117.0 & 117.0 \\
\hline Telegraph & 4 & 176.0 & 0.0 & 0.0 & 176.0 & 176.0 \\
\hline Johnston Press & 3 & 142.5 & 110.6 & 77.6 & 14.9 & 206.3 \\
\hline Midland Independent & 3 & 112.8 & 12.7 & 11.3 & 99.4 & 124.7 \\
\hline Scottish Radio Holdings & 3 & 10.9 & 1.0 & 9.5 & 10.2 & 12.1 \\
\hline Dalgety & 3 & 130.0 & 0.0 & 0.0 & 130.0 & 130.0 \\
\hline Highland Distillers & 3 & 72.2 & 0.0 & 0.0 & 72.2 & 72.2 \\
\hline Charterhouse & 2 & 6.4 & 0.2 & 2.9 & 6.2 & 6.5 \\
\hline Scottish Media Group & 2 & 56.0 & 0.0 & 0.0 & 56.0 & 56.0 \\
\hline Newsquest & 1 & 320.0 & & & 320.0 & 320.0 \\
\hline
\end{tabular}

$\mathrm{N}=$ Number of observations,

$\mathrm{SD}=$ Standard deviation, and

$\mathrm{CV}=$ Coefficient of variation, i.e., SD/Mean. 
Table 3

Test of Value Relevance of Brands

Correlations, and Coefficient Values and t-statistics for the Regression:

$M V E_{j t}=\sum_{Y=84}^{98} a_{0 Y} Y_{R D U M_{Y}}+\sum_{j=1}^{32} a_{1 j}$ FIRM $_{j}+a_{2} B V E_{j t}+a_{3} N I_{j t}+a_{4} B R A N D_{j t}+e_{j t}$

Panel A: Correlations Among Variables Used in Regressions

\begin{tabular}{lccc}
\hline & $B V E$ & $N I$ & $B R A N D$ \\
\hline$M V E$ & $0.55^{* * *}$ & $0.81^{* * *}$ & $0.86^{* * *}$ \\
$B V E$ & & $0.50^{* * *}$ & $0.23^{* * *}$ \\
$N I$ & & $0.74^{* * *}$ \\
\hline
\end{tabular}

Panel B: Coefficient values and t-statistics for the regression:

\begin{tabular}{lcc}
\hline Variable & $\begin{array}{c}\text { Predicted } \\
\text { signs }\end{array}$ & $\begin{array}{c}\text { Regression } \\
\text { coefficient } \\
\text { (white t-stat) } \\
\mathrm{N}=227\end{array}$ \\
\hline \multirow{2}{*}{$B V E$} & + & -0.06 \\
& & -0.17 \\
$N I$ & + & 2.27 \\
BRAND & & $3.26^{* * *}$ \\
& + & 1.24 \\
$\operatorname{Adj} R^{2}$ & & $3.27^{* * *}$ \\
\hline
\end{tabular}

$M V E \quad$ = market value of equity.

$B V E \quad$ = book value of equity (excluding brands).

$N I \quad=$ net income.

$B R A N D \quad=$ brand assets.

$Y R D U M_{Y} \quad=1$ if year $=Y$, and 0 otherwise,

FIRM $_{j} \quad=1$ for the $j$ th firm, and 0 for others.

$*, * *, * * *$ indicate significance at 10, 5, and 1 percent levels (one-tailed for coefficients whose signs we predict).

Five outliers, i.e., observations with DFBETAS exceeding 1 in absolute value for any coefficient, were deleted for the regression in Panel B. 


\section{Table 4}

\section{Test of Reliability--Value Relevance of Brands in Subsamples Partitioned by} Contracting Incentives Dummies

Correlations, and Coefficient Values and t-statistics for the Regressions:

$$
\begin{aligned}
& M V E_{j t}=\sum_{Y=84}^{98} b_{0 Y} Y_{R D U M_{Y}}+\sum_{j=1}^{32} b_{1 j} \text { FIRM }_{j}+b_{2} B V E_{j t}+b_{3} N I_{j t}+b_{4} B R A N D_{j t}+ \\
& b_{5} B V E^{*} D \_ \text {nocltest }_{j t}+b_{6} N I^{*} D \_ \text {nocltest }_{j t}+b_{7} \text { BRAND }^{*} D \_ \text {nocltest }_{j t}+e_{j t} \quad \text { (Model 1) } \\
& M V E_{j t}=\sum_{Y=84}^{98} c_{0 Y} Y_{R D U M_{Y}}+\sum_{j=1}^{32} c_{1 j} \text { FIRM }_{j}+c_{2} B V E_{j t}+c_{3} N I_{j t}+c_{4} \text { BRAND }_{j t}+ \\
& c_{5} B V E * D \_ \text {lolevg }_{j t}+c_{6} N I^{*} D \_ \text {lolevg }_{j t}+c_{7} B R A N D * D \_l o l e v g_{j t}+e_{j t}
\end{aligned}
$$

\begin{tabular}{|c|c|c|c|}
\hline Variable & $\begin{array}{c}\text { Predicted } \\
\text { signs }\end{array}$ & $\begin{array}{l}\text { Model 1 } \\
\mathrm{N}=230\end{array}$ & $\begin{array}{l}\text { Model } 2 \\
\mathrm{~N}=230\end{array}$ \\
\hline$B V E$ & + & $\begin{array}{c}-0.42 \\
(-1.10)\end{array}$ & $\begin{array}{l}-0.60 \\
(-1.52)^{*}\end{array}$ \\
\hline$N I$ & + & $\begin{array}{l}7.19 \\
(5.16)^{* * *}\end{array}$ & $\begin{array}{l}6.72 \\
(5.25)^{* * *}\end{array}$ \\
\hline$B R A N D$ & + & $\begin{array}{c}0.35 \\
(0.94)\end{array}$ & $\begin{array}{c}0.40 \\
(1.05)\end{array}$ \\
\hline$B V E^{*} D \_$nocltest & $?$ & $\begin{array}{l}1.03 \\
(1.89)^{* *}\end{array}$ & \\
\hline$B V E^{*} D$ _lolevg & $?$ & & $\begin{array}{l}1.27 \\
(2.29)^{* *}\end{array}$ \\
\hline$N I * D \_$nocltest & $?$ & $\begin{array}{l}-7.96 \\
(-5.19)^{* * *}\end{array}$ & \\
\hline$N I^{*} D \_l o l e v g$ & $?$ & & $\begin{array}{l}-7.65 \\
(-5.45)^{* * *}\end{array}$ \\
\hline BRAND*D_nocltest & + & $\begin{array}{l}1.59 \\
(2.98)^{* * *}\end{array}$ & \\
\hline BRAND*D_lolevg & + & & $\begin{array}{c}1.51 \\
(2.80)^{* * *}\end{array}$ \\
\hline $\operatorname{Adj} R^{2}$ & & 0.96 & 0.96 \\
\hline
\end{tabular}

Panel A: Correlations Among Variables Used in Regressions ${ }^{a}$

\begin{tabular}{lcc}
\hline & $D$ nocltest & D_lolevg \\
\hline MVE & 0.05 & $0.31^{* * *}$ \\
BVE & $0.27^{* * *}$ & $0.35^{* * *}$ \\
NI & 0.03 & $0.26^{* * *}$ \\
BRAND & 0.03 & $0.28^{* * *}$ \\
D_nocltest & & $0.36^{* * *}$ \\
\hline
\end{tabular}

Panel B: Coefficients and t-statistics for regression models (1) and (2)

(White heteroskedasticity-adjusted t-statistics in parentheses) 


\section{Table 5}

Share Price Reactions to Announcements of Brand Capitalization: All Firms, and Subsamples Partitioned by Contracting Incentives

Coefficient values and t-statistics for the regressions:

$$
\begin{aligned}
& A R_{j t}=d_{0}+d_{1}\left(B R A N D_{j t} / M V E_{j, t-1}\right)+e_{j t}, \\
A R_{j t}= & f_{0}+f_{1}\left(B R A N D_{j t} / M V E_{j, t-1}\right)+f_{2} D_{-} \text {nocltest }+ \\
& f_{3}\left(B R A N D_{j t} / M V E_{j, t-1}^{*} D_{-} \text {nocltest }\right)+e_{j t}, \\
\text { and } & \\
A R_{j t}= & g_{0}+g_{1}\left(B R A N D_{j t} / M V E_{j, t-1}\right)+g_{2} D_{-} \text {lolevg }+ \\
& g_{3}\left(B R A N D_{j t} / M V E_{j, t-1} * D_{-} \text {lolevg }\right)+e_{j t} .
\end{aligned}
$$

\begin{tabular}{|c|c|c|c|c|}
\hline \multirow[b]{2}{*}{ Variable } & \multirow[b]{2}{*}{$\begin{array}{c}\text { Predicted } \\
\text { signs }\end{array}$} & \multicolumn{3}{|c|}{$\begin{array}{c}\text { Regression coefficient } \\
\text { (white t-stat) } \\
\mathrm{N}=24 \\
\end{array}$} \\
\hline & & Model 1 & Model 2 & Model3 \\
\hline Intercept & $?$ & $\begin{array}{c}0.01 \\
(-0.20)\end{array}$ & $\begin{array}{c}0.02 \\
(0.62)\end{array}$ & $\begin{array}{c}-0.06 \\
(-1.36)\end{array}$ \\
\hline$B R A N D / M V E$ & $+/-$ & $\begin{array}{c}0.12 \\
(3.21)^{* * *}\end{array}$ & $\begin{array}{c}0.08 \\
(2.76)^{* * *}\end{array}$ & $\begin{array}{c}0.16 \\
(3.35)^{\text {*** }}\end{array}$ \\
\hline D_nocltest & $?$ & & $\begin{array}{c}-0.05 \\
(-0.97)\end{array}$ & \\
\hline D_lolevg & $?$ & & & $\begin{array}{c}0.07 \\
(1.13)\end{array}$ \\
\hline$B R A N D / M V E * D \_$nocltest & + & & $\begin{array}{c}0.21 \\
(1.07)\end{array}$ & \\
\hline BRAND/MVE *D_lolevg & + & & & $\begin{array}{c}-0.00 \\
(-0.01)\end{array}$ \\
\hline $\operatorname{Adj} R^{2}$ & & 0.02 & 0.03 & 0.08 \\
\hline
\end{tabular}

Model 2

Model 3

$A R_{j t} \quad=$ announcement period (days -10 to +10 ) abnormal returns for the $j$ th firm in year $t$ (estimated as the difference between actual returns and expected returns based on market model parameters estimated over the 60 trading days ending 30 days before the announcement).

$B R A N D_{j t}=$ brand assets at the end of year $t$.

$M V E_{j, t-1}=$ market value of equity at the end of year $t-1$.

D_nocltest and D_lolevg are as defined in Table 4.

$*, * *, * * *$ indicate significance at 10,5 , and 1 percent levels. 